\title{
KONDISI SANITASI DASAR MASYARAKAT DESA PINGARAN ULU KECAMATAN ASTAMBUL KABUPATEN BANJAR TAHUN 2014
}

\author{
Tien Zubaidah, Arifin \\ Poltekkes Kemenkes Banjarmasin Jurusan Kesehatan Lingkungan Banjarbaru \\ Jl. H. Mistar Cokroksumo No. 1A Kota Banjarbaru \\ e-mail: arrasyid.hanif@gmail.com
}

\begin{abstract}
Basic Sanitary Conditions At Pingaran Ulu Village Community Subdistrict Astambul, Banjar District Year 2014. Basic sanitation monitoring efforts are directed towards environmental factors that can constitute the chain of transmission of the disease, which include water supply, wastewater disposal, disposal of human waste / family latrines and waste management. Basic sanitary conditions must be able to meet the physical needs, the reality is difficult to be met and most of the population because of the level of education, social science and economics. To know the basic sanitary conditions descriptive survey research is to use the checklist and guided interview questionnaire to 249 households. The purpose of the study to determine the means of water supply, disposal of excreta and wastewater, waste management, and the factors that influence those described in the form of frequency distribution tables and narrative. The result showed a percentage overview of basic sanitation Pingaran Ulu villagers who do not qualify ie water supply as much as $80 \%$ comes from the river water, excreta disposal as much as $89 \%$ of people throw in the river, wastewater by $75 \%$ without management, waste management how to burn garbage as much as $56 \%$. This is due to the level of education, low socioeconomic majority. It is expected the public to pay attention to the quality of basic sanitation, income generation so that people can repair and build basic sanitation facilities and healthy home by way of mutual assistance / social gathering under the guidance of the relevant service agencies. For the Banjar District Health Office and Health Center Astambul should be able to spearhead the development of basic sanitation and a healthy home.
\end{abstract}

Keywords: basic sanitation; village Ulu Pingaran

\begin{abstract}
Abstrak: Kondisi Sanitasi Dasar Masyarakat Desa Pingaran Ulu Kecamatan Astambul Kabupaten Banjar Tahun 2014. Sanitasi dasar adalah usaha-usaha pengawasan yang ditujukan terhadap faktor-faktor lingkungan yang dapat merupakan mata rantai penularan penyakit, yang meliputi penyediaan air bersih, pembuangan air limbah, pembuangan kotoran manusia / jamban keluarga dan pengelolaan sampah. Untuk mencapai sanitasi dasar sukar dipenuhi karena sebagian besar penduduk karena faktor tingkat pendidikan, pengetahuan dan sosial ekonomi. Untuk mengetahui kondisi sanitasi dasar dilakukan penelitian bersifat survei deksriptif dengan cheklist dan wawancara terpimpin menggunakan kuesioner kepada $249 \mathrm{KK}$. Tujuan penelitian untuk mengetahui sarana penyediaan air bersih, pembuangan tinja dan air limbah, pengelolaan sampah dan faktor-faktor yang mempengaruhi yang diuraikan dalam bentuk tabel distribusi frekuensi dan narasi. Hasil penelitian diperoleh persentase kualitas sanitasi dasar masyarakat Desa Pingaran Ulu yang tidak memenuhi syarat antara lain penyediaan air bersih $80 \%$ diperoleh dari air sungai, pembuangan tinja $89 \%$ di sungai, air limbah tanpa pengelolaan 75\%, pengelolaan sampah dengan cara membakar sampah sebanyak 56\%. Kondisi tersebut terkait dengan tingkat pendidikan, sosial ekonomi yang mayoritas rendah. Diharapkan kepada masyarakat untuk memperhatikan kualitas sanitasi dasar, peningkatan pendapatan sehingga masyarakat dapat memperbaiki dan membangun fasilitas sanitasi dasar dan rumah sehat dengan cara gotong royong / arisan dibawah binaan dinas instansi yang terkait. Untuk itu Dinas Kesehatan Kabupaten Banjar dan Puskesmas Astambul harus mampu menjadi ujung tombak dalam pembinaan sanitasi dasar dan rumah sehat.
\end{abstract}

Kata kunci: Sanitasi dasar; Desa Pingaran Ulu 


\section{PENDAHULUAN}

Kondisi lingkungan yang tidak memenuhi syarat kesehatan merupakan faktor resiko penularan berbagai penyakit, khususnya penyakit berbasis lingkungan. Beberapa penelitian menunjukkan bahwa sanitasi dasar yang tidak memenuhi syarat mempunyai hubungan terhadap kejadian penyakit. Penelitian Wahyuni (2005) ${ }^{1}$ menemukan bahwa balita yang menderita demam berdarah (DBD) 64\% bertempat tinggal di rumah yang mempunyai sarana pembuangan air limbah tidak memenuhi syarat. Yuwono (2008) ${ }^{2}$ menemukan lingkungan fisik rumah yang tidak memenuhi syarat merupakan faktor risiko terjadinya pneumonia pada balita. Wulandari $(2009)^{3}$ menemukan sanitasi rumah yang buruk dapat menyebabkan balita terkena diare.

Sanitasi merupakan hal yang penting dalam kesehatan lingkungan, mengingat sanitasi sebagai upaya untuk mengurangi resiko penularan penyakit dan gangguan kesehatan lainnya. Masalah sanitasi sering muncul di kawasan permukiman pedesaan. Sanitasi yang buruk akan berdampak pada gangguan kesehatan masyarakat. Masyarakat, terutama di perdesaan, kurang memahami pentingnya sanitasi bagi kesehatan mereka, yang salah satunya disebabkan rendahnya pengetahuan mereka.

Kondisi ini menyebabkan banyak masyarakat yang tidak memiliki jamban. Pada umumnya masyarakat memanfaatkan hutan/kebun, sungai sebagai tempat BAB. Sebagian yang memiliki jamban tapi tidak memenuhi standar kesehatan dan tidak digunakan sebagaimana mestinya. Ketersediaan fasilitas jamban belum memadai ${ }^{4}$

Sebagai dasar pemikiran dalam masalah ini adalah masih kurangnya sanitasi dasar masyarakat. Pada umumnya masyarakat di Desa Pingaran Ulu memperoleh air bersih sebagai air minum dan air masak dari air sungai Martapura, masih banyaknya masyarakat yang membuang tinja di sungai, dan sebagainya. Sebagai perumusan masalah dalam penelitian ini adalah " bagaimana kondisi sanitasi dasar serta faktor apa yang mempengaruhi?"

Tujuan penelitian ini adalah untuk mengetahui sanitasi dasar di Desa Pingaran Ulu Kecamatan Astambul Kabupaten Banjar tahun 2014.
Manfaat penelitian bagi responden untuk memberikan wawasan serta pengetahuan responden tentang pentingnya sanitasi dasar. Bagi pemerintah daerah, hasil penelitian ini dapat memberikan bahan masukan serta sumbangan pemikiran tentang kesehatan lingkungan khususnya mengenai sanitasi dasar dan rumah sehat.

Jenis penelitian yang dilaksanakan adalah penelitian survei bersifat deskriptif yaitu untuk mengetahui gambaran sanitasi dasar dan kondisi rumah di Desa Pingaran Ulu Kecamatan Astambul Kabupaten Banjar. Penelitian ini dilaksanakan di Desa Pingaran Ulun Kecamatan Astambul Kabupaten Banjar Provinsi Kalimantan Selatan. Waktu penelitian ini dilaksanakan selama 1 bulan, dimulai pada bulan Mei s/d Juni 2014.

Desa Pingaran Ulu memliki jumlah penduduk sebanyak 2188 jiwa dengan jumlah kepala keluarga terdiri dari $741 \mathrm{KK}$. Penentuan jumlah sampel dalam penelitian menggunakan rumus Slovin ${ }^{5}$ yaitu : $\mathrm{N}=$ $\mathrm{n} / \mathrm{N}(\mathrm{d})^{2}+1$. Dari hasil perhitungan diperoleh 256 sampel, namun dalam penelitian ini sampel yang diperoleh hanya sebanyak 249 KK. Pengambilan sampel menggunakan teknik pengambilan simple random sampling.

Data primer diperoleh dengan menggunakan checklist dan wawancara kepada responden. Data sekunder mengenai jumlah penduduk diperoleh dari Kantor Kecamatan Astambul, dan studi literatur lainnya. Dalam penelitian ini, setelah mendapat izin dari kepala desa dilakukanlah pengumpulan data penelitian yaitu dengan mendatangi rumah, responden yang terpilih diwawancarai selanjutnya dilakukan penilaian kondisi sanitasi dasar dengan menggunakan lembar checklist.

Data yang telah terkumpul, selanjutnya diolah secara manual dengan bantuan komputer. Adapun kegiatan yang dilakukan adalah sebagai berikut:

\section{Editing}

Memeriksa daftar pertanyaan dan kelengkapan jawaban setelah data terkumpul, kesesuaian jawaban atau relevansi jawaban, dll.

Koding

Mengklasifikasikan jawaban - jawaban dari para responden ke dalam kategori-kategori, 
dengan cara memberi tanda/kode berbentuk angka pada masing-masing jawaban. Tabulating

Membuat tabulasi atau table jawaban-jawaban yang sudah di koding, sehingga mempermudah perhitungan frekwensi data masing-masing kategori jawaban dan tabel frekuensi distribusi. Sedangkan penyajian data dilakukan dengan tabel distribusi frekwensi.
Untuk mengetahui gambaran sanitasi dasar dan kondisis rumah penduduk Desa Pingaran Ulu maka data dinalisis secara deskriptif.

\section{HASIL DAN PEMBAHASAN}

\section{A. Hasil}

Kondisi sosial ekonomi keluarga di Desa Pingaran Ulu dapat dilihat pada tabel berikut.

Tabel 1. Penghasilan Penduduk di Desa Pingaran Ulu RT. 01 s.d 07 Tahun 2014

\begin{tabular}{clcc}
\hline No. & \multicolumn{1}{c}{ Kategori } & Jumlah & $\%$ \\
\hline 1 & $<$ Rp.1.000.000 per bulan & 157 & 63 \\
2 & Rp.1.100.000 - Rp. 2.000.000 per bulan & 77 & 31 \\
3 & Rp.2.100.000 - Rp. 3.000.000 per bulan & 10 & 4 \\
4 & $>$ Rp.3.000.000 per bulan & 5 & 2 \\
\hline & Jumlah & 249 & 100 \\
\hline
\end{tabular}

Terlihat bahwa sebagian besar memiliki penghasilan rata-rata < Rp.1000.000,per bulan (63\%). Hal ini karena jenis pekerjaan yang banyak adalah sebagai pedagang kecil (swasta) dan petani. Jenis pekerjaan paling banyak adalah sebagai petani $(46,7 \%)$ dan pedagang $(40,5 \%)$.
Berdasarkan tingkat pendidikan bahwa tingkat pendidikan penduduk paling banyak adalah pendidikan SD/sederajat $(38,5 \%)$ dan SMP/sederajat $(27,7 \%)$. Lebih jelas dapat dilihat pada tabel berikut.

Tabel 2. Distribusi Penduduk Berdasarkan Tingkat Pendidikan di Desa Pingaran Ulu RT. 01 s.d 07 Tahun 2014

\begin{tabular}{|c|c|c|c|}
\hline No. & Pendidikan & Jumlah & $\%$ \\
\hline 1. & SD (sederajat) & 96 & 38,5 \\
\hline 2. & SMP (sederajat) & 69 & 27,7 \\
\hline 3. & SMA (sederajat) & 57 & 23 \\
\hline 4. & Perguruan Tinggi & 6 & 2,4 \\
\hline 5. & Tidak Sekolah & 21 & 8,4 \\
\hline & Jumlah & 249 & 100 \\
\hline
\end{tabular}

Kondisi kesehatan lingkungan di Desa Pingaran Ulu meliputi :

\section{Penyediaan air bersih}

Diketahui bahwa sumber air minum yang paling banyak digunakan masyarakat adalah air permukaan (air sungai) sebanyak $80 \%$. Untuk keperluan mandi, cuci dan kakus (MCK) mayoritas masyarakat menggunakan air permukaan (sungai). Secara fisik, air sungai yang digunakan oleh masyarakat tidak berbau, tidak berasa, terlihat kurang jernih, dan terlihat kurang bersih dikarenakan masih banyak sampah yang berada di aliran sungai.

Masyarakat yang mempunyai sumur gali sebagian besar tidak mempunyai bibir sumur, dinding sumur, lantai sumur dan jarak < 11 meter dari sumber pencemar (kandang hewan, air limbah rumah tangga). Selain itu, dari segi kontruksi SGL warga masih banyak yang belum memenuhi persyaratan, seperti dinding dan lantai sumur yang tidak tersedia. 


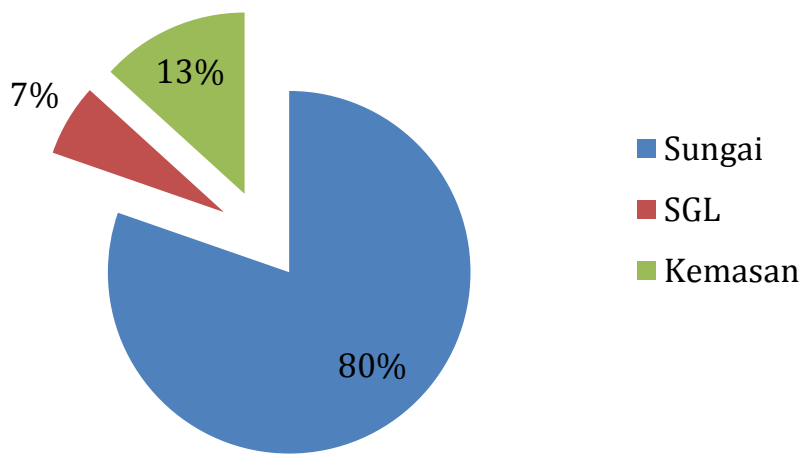

Gambar 1. Penyediaan Air Bersih di Desa Pingaran Ulu Tahun 2014

\section{Pembuangan tinja dan air limbah}

Dari 249 KK yang didata, penghuni rumah yang memiliki kebiasaan selalu membuang tinja di sungai dekat rumah sebanyak $89 \%$ dan hanya $10 \%$ yang membuang tinjanya di jamban/WC.

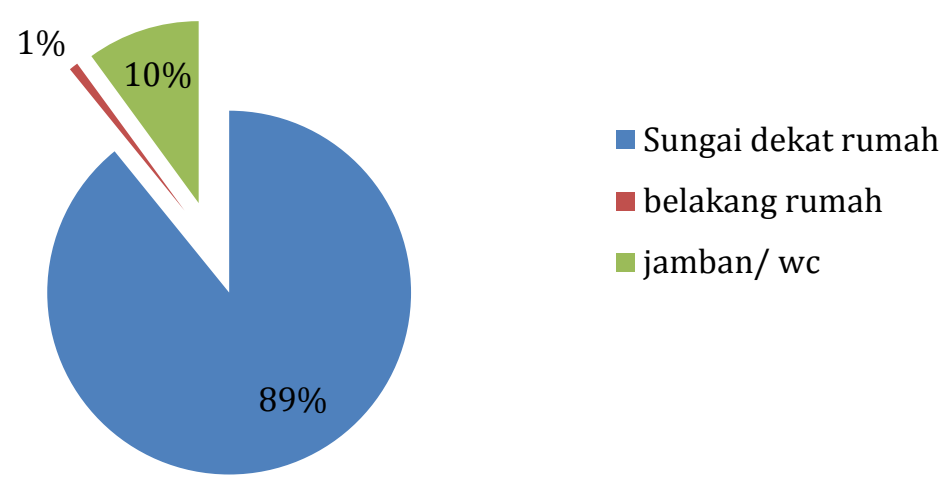

Gambar 2. Sarana Tempat Buang Air Besar di Desa Pingaran Ulu Tahun 2014

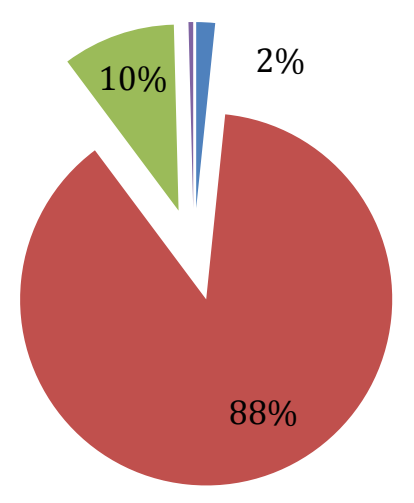

$$
\begin{aligned}
& \text { cemplung dengan } \\
& \text { septictank } \\
& \text { cemplung tanpa } \\
& \text { septictank } \\
& \text { leher angsa dengan } \\
& \text { septictank } \\
& \text { leher angsa tanpa } \\
& \text { septictank }
\end{aligned}
$$

Gambar 3. Jenis Jamban Keluarga di Desa Pingaran Ulu Tahun 2014

Jenis jamban yang paling banyak dimiliki yaitu jenis cemplung tidak dengan septictank sebanyak $88 \%$ dan jenis leher angsa dengan septictank sebanyak $10 \%$.

Dalam pengelolaan limbah rumah tangga, sebanyak $75 \%$ membiarkan air limbah rumah tangga tergenang di sekitar rumah, sedangkan yang memiliki sumur resapan sebagai tempat pembuangan air limbah hanya $7 \%$. 


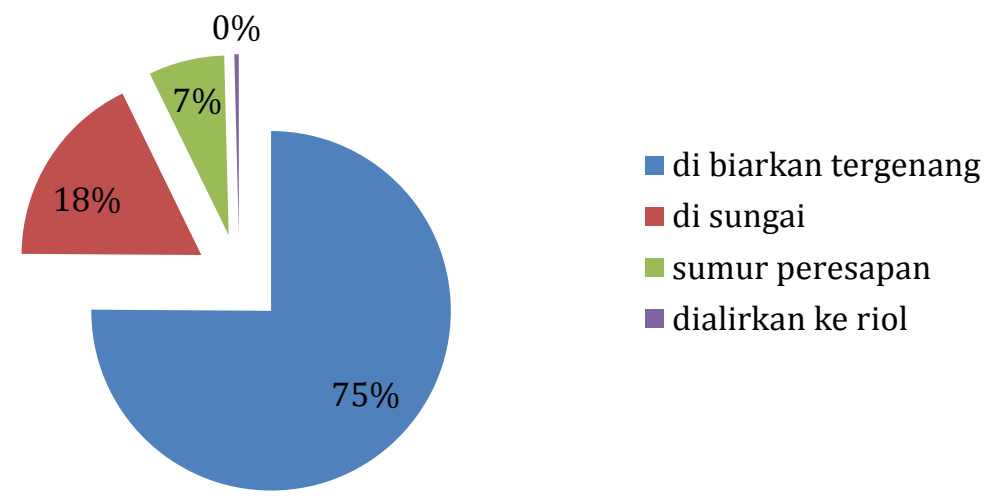

Gambar 4. Pembuangan Air Limbah di Desa Pingaran Ulu Tahun 2014

\section{Pengelolaan sampah}

Dari hasil observasi 249 responden, yang melakukan pengelolaan sampah de-

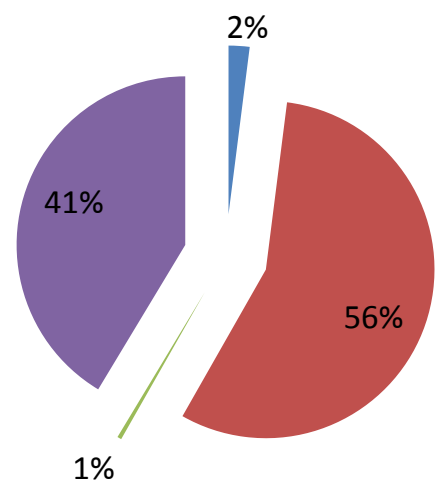

ngan cara dibakar sebanyak $56 \%$ dan dibuang ke TPS hanya $1 \%$. dikubur dibakar

$\square$ ke TPS $\quad$ sungai

Gambar 5. Pengelolaan Sampah di Desa Pingaran Ulu Tahun 2014

\section{B. Pembahasan}

\section{Penyediaan air}

Persyaratan kualitas air bersih yang ada dan diberlakukan di Indonesia harus memenuhi standar yang meliputi persyaratan fisika, kimia, mikrobiologi dan radioaktif. Persyaratan air bersih diatur dalam Keputusan Menteri Kesehatan Republik Indonesia Nomor 907/Menkes/ SK/VII/2002 ${ }^{6}$ tentang Syarat-Syarat dan Pengawasan Kualitas Air Minum.

Secara kuantitas, jumlah air yang dibutuhkan masyarakat Desa Pingaran Ulu sudah lebih dari cukup, namun secara kualitas, air sungai yang digunakan masyarakat secara fisik tidak berbau, tidak berasa, namun untuk warna air sungai yang kurang jernih ini disebabkan kekeruhan air yang tinggi terutama pada saat setelah hujan.

Masyarakat Desa Pingaran Ulu sudah melakukan upaya penyehatan air khusus- nya untuk air minum yaitu dengan cara sederhana, yaitu air ditampung dan diendapkan dengan terlebih dahulu diberi obat air (tawas), namun masyarakat memasukkan obat air ini tanpa takaran karena masyarakat belum mengetahui takaran tawas secara tepat. Prinsip masyarakat adalah semakin banyak tawas yang dicampurkan di air yang keruh, maka air tersebut akan cepat jernih.

Tawas/alum adalah sejenis koagulan dengan rumus kimia $\mathrm{Al}_{2} \mathrm{SO}_{4} 11 \mathrm{H}_{2} \mathrm{O}$ atau 14 $\mathrm{H}_{2} \mathrm{O}$ atau $18 \mathrm{H}_{2} \mathrm{O}$ umumnya yang digunakan adalah $18 \mathrm{H}_{2} \mathrm{O}$. Tawas dapat digunakan sebagai penjernih air karena dapat mengendapkan kotoran di dalam air. Tawas termasuk bahan kimia yang masuk klasifikasi berbahaya. Mengkonsumsi tawas secara berlebihan dapat menyebabkan kerusakan parah pada kesehatan, yaitu dapat menyebabkan iritasi organ pencernaan ${ }^{7}$ 
Pengolahan air dengan tawas tidak mematikan mikroorganisme patogen, sehingga untuk penyediaan air minum masyarakat harus mengkonsumsi air minum yang sehat dengan memasak terlebih dahulu air yang telah diolah tadi.

\section{Pembuangan tinja}

Masyarakat Desa Pingaran Ulu masih banyak menggunakan jamban di sungai karena kondisi geografis yakni dekat dengan sungai, masyarakat beranggarapan adalah sangat praktis untuk membuang tinja di sungai.

Menurut Soenarto (2000) jamban merupakan salah satu sarana fisik penunjang kesehatan masyarakat untuk pembuangan sehari hari masyarakat yang terdiri dari buangan dari hasil buangan dari kakus, yang terdiri dari tinja (faeces) dan air seni (urine). Sarana jamban bertujuan untuk mengurangi eksploitasi air tanah dangkal, dan sebagai lokalisasi pembuangan tinja dan limbah cair lainnya secara terpusat, untuk menjaga kebersihan air baik air tanah maupun air permukaan seperti sungai, danau, dan hal ini untuk meningkatnya derajat kesehatan lingkungan dan daya dukung lingkungan.

\section{Pembuangan air limbah}

Masyarakat Desa Pingaran Ulu belum mengelola limbahnya beranggapan karena kondisi geografis yakni dekat dengan sungai, sehingga air limbah yang dihasilkan rumah tangga dengan sendirinya akan mengalir ke sungai sehingga masyarakat merasa tidak perlu adanya saluran khusus air limbah.

Perhatian akan masyarakat terhadap lingkungan hidup masih sangat dibutuhkan. Hal ini cukup beralasan mengingat besarnya kemungkinan ancaman terhadap kesehatan dan sanitasi masyarakat sekitarnya. Tidak terkecuali perhatian masyarakat terhadap limbah rumah tangga. Air limbah yang dibiarkan tergenang di sekitar rumah tanpa adanya pengelolaan dapat menimbulkan bau yang tidak sedap, kerusakan terhadap biota air dan pencemaran lain terhadap lingkungan hidup.

Sebagai contoh limbah deterjen. Limbah ini bila dibuang sembarang dapat membentuk genangan air dan akan menimbulkan bau yang tidak sedap. Bila meresap ke dalam tanah, limbah ini akan mempe- ngaruhi kondisi air bawah tanah. Air bawah tanah yang sudah tercemar oleh bahan kimia kandungan limbah deterjen berpengaruh pada kualitas air sumur sebagai sumber air minum di suatu lingkungan masyarakat. Bila dibiarkan mengalir ke sungai, maka akan menimbulkan kerusakan pada ekosistem air tempat tersebut. Bahan kimia yang terlarut dalam air akan mempengaruhi kehidupan organisme dan mikroorganisme dalam air. Kehidupan organisme seperti bermacam tumbuhan air dan ikan. Kehidupan mikroorganisme seperti plankton, alga, ganggang biru, serta hewan dan tumbuhan bersel satu lainnya. Mikroorganisme tersebut merupakan sumber makanan bagi ikan-ikan yang hidup dalam air ${ }^{9}$

Mengingat dampak limbah rumah tangga terhadap lingkungan hidup sangat besar maka diperlukan tindakan dan kebijakan untuk mengelola limbah rumah tangga dengan baik. Setiap keluarga mempunyai peranan dalam mengelola limbah rumah tangga. Misalnya dengan tidak membuang limbah sembarang, ataupun membiarkannya tergenang/tidak mengalir atau ke sungai yang banyak terdapat ikan. Mungkin ada baiknya disalurkan ke lubang khusus pembuangan limbah rumah tangga.

\section{Pengelolaan sampah}

Terbatasnya tempat pembuangan sampah di Desa Pingaran Ulu, masyarakat lebih banyak membakar sampah kering, sedangkan sampah basah biasanya diberikan kepada hewan ternak. Hal lain karena kondisi geografis, dekat dengan sungai menjadi faktor kepraktisan dalam pembuangan sampah.

Kebiasaan masyarakat di Desa Pingaran Ulu yang membuang sampah ke sungai atau dibakar dikarenakan di sekitar wilayah desa tidak terdapat fasilitas tempat pembuangan sampah sementara.

Sampah dapat menimbulkan banyak hal negatif bagi lingkungan hidup. Tidak hanya lingkungan hidup saja, sampah juga dapat menimbulkan hal negatif bagi manusia. Dampaknya akan mengenai kesehatan tubuh secara langsung dan tidak langsung seperti adanya pencemaran udara, pencemaran air, gangguan estetika, hingga dampak sosial yang lain.

Dengan adanya sampah yang berlebih, dampak yang ditimbulkan akan menyebab- 
kan penyakit diare, kolera, dan tifus yang dapat menyebar dengan cepat. Hal tersebut dikarenakan adanya sampah yang tidak dikelola dengan benar atau pengelolaan sampah yang tidak mencukupi. Selain itu juga bisa menyebabkan adanya penyakit demam berdarah, karena sampah biasanya menjadi sarang berkembang biaknya nyamuk pada daerah yang berkubang air.

Sampah yang tidak dikelola dengan benar, dapat menimbulkan jamur dan bakteri. Jamur tersebut bisa menjadi suatu penyakit, seperti jamur yang dapat berkembang pada kulit tubuh. Dampak lain yang sangat tidak diinginkan tentu adanya penyakit yang dapat menyebar pada makanan. Penyakit tersebut ditimbulkan oleh cacing pita atau yang juga disebut dengan taenia. Cacing tersebut masuk kedalam tubuh binatang ternak melalui makanannya, jika makanan hewan tersebut tidak sengaja berasal dari sampah atau sisa makanan 10

Sebuah penelitian melaporkan bahwa sekitar 53,7\% responden berperilaku kurang baik dalam menangani sampah dan masih banyaknya sejumlah warga di sekitar bantaran sungai yang merasa lebih praktis membuang sampah ke dalam sungai ${ }^{11}$

Sudah seharusnya masyarakat lebih peduli lagi untuk menciptakan lingkungan yang lebih baik. Cara menanggulangi sampah tentu dengan adanya pengelolaan yang baik, di mana sudah seharusnya sampah terangkut semua dari TPS ke TPA. Selain itu, ada baiknya jika pengelolaan sampah dilakukan oleh diri sendiri terlebih dahulu, atau lingkungan kecil dahulu. Hal ini dimaksudkan agar mengurangi sampah yang ada dan ikut serta membantu pemerintah.

Selain pengumpulan sampah, masyarakat juga dapat turut serta dalam pengelolaan sampah dengan pemusnahan sampah. Pemusnahan sampah tersebut dapat dengan ditanam, dibakar atau dijadikan sampah produktif. Saat ini telah banyak orang yang menjadikan sampah sebagai sampah produktif yang pada akhirnya dapat memberikan keuntungan sendiri bagi yang mengelolanya.

\section{PENUTUP}

Kondisi sanitasi dasar masyarakat Desa Pingaran Ulu Kecamatan Astambul Kabupaten Banjar masih rendah. Penyediaan air bersih berasal dari air sungai dengan pengolahan air yang masih sederhana, masyarakat masih banyak yang membuang tinjanya di sungai, pengelolaan air limbah rumah tangga yang belum saniter serta pengelolaan sampah yang belum tepat.

Faktor-faktor yang mempengaruhi rendahnya kondisi sanitasi dasar kemungkinan dikarenakan tingkat pendidikan dan sosial ekonomi masyarakat yang masih rendah.

Penyediaan air yang berkualitas di masyarakat dapat dilakukan dengan pengolahan air berupa proses penjernihan air dengan PAC (Poly Aluminium Chloride). PAC memiliki beberapa keunggulan dibandingkan dengan koagulan lain yaitu PAC tidak menjadi keruh bila pemakaiannya berlebihan dan lebih cepat membentuk flok daripada koagulan biasa.

1. Mengatasi pembuangan tinja di sungai, dapat diadakan arisan jamban sehat.

2. Perubahan perilaku masyarakat melalui peningkatan pengetahuan masyarakat melalui penyuluhan yang instensif.

\section{KEPUSTAKAAN}

1. Wahyuni. dkk. 2005. Peran Faktor Lingkungan dan Perilaku Terhadap Penularan Demam Berdarah Dengue di Kota Mataram. Jurnal Kesehatan Lingkungan Vol 2 No.1 Juli 2005

2. Yuwono, Tulus Aji. 2008. Faktor-faktor Lingkungan Fisik Rumah yang Berhubungan dengan Kejadian Pneumonia pada Anak Balita di Wilayah Kerja Puskesmas Kawunganten Kabupaten Cilacap. Tesis. Program Pascasarjana Universitas Diponegoro, Semarang.

3. Wulandari. 2009. Hubungan Karakteristik Keluarga, Perilaku Keluarga dan Letak Bangunan Terhadap Kondisi Kesehatan Rumah di Desa Bojongsari Kecamatan Kembaran Kabupaten Banyumas. Skripsi. Universitas Muhammadiyah Purwokerto.

4. Ricky 2007 dalam Seri Asnawati Munthe. 2009. Hubungan Jamban dengan Kejadian Penyakit Demam Typoid Pada Anak Usia 5 - 12 Tahun Di Daerah Tertinggal Pesisir Pulau Tello 
Kecamatan Pulau Pulau Batu Kabupaten Nias Selatan Tahun 2009. Skripsi. Universitas Sari Mutiara Indonesia. Medan.

5. Husein, Umar. 2004. Metode Penelitian untuk Skripsi dan Tesis Bisnis. Cetakan ke-6. Pt. Raja Grafindo Persada. Jakarta.

6. Keputusan Menteri Kesehatan Republik Indonesia Nomor 907/Menkes/SK/VII/ 2002 tentang Syarat-Syarat dan Pengawasan Kualitas Air Minum.

7. Hülya Genç-Fuhrman, dkk. 2006. Removal of $\mathrm{As}, \mathrm{Cd}, \mathrm{Cr}, \mathrm{Cu}, \mathrm{Ni}$ and $\mathrm{Zn}$ from polluted water using an iron based sorbent. Denmark: Technical University of Denmark.

8. Soenarto, 2000, Pemanfaatan Sarana Komunal, Universitas Indonesia: Jakarta Mulia, 2007, Sanitasi Lingkungan, Gramedia : Jakarta
9. Uda, Awak, 2014. http://www.matrapendidikan.com/20 14/02/limbah-rumah-stangga-danlingkungan-hidup.html. Diakses tanggal 12 Juni 2014

10. Mardiana. 1997. Peranan Lalat (Family Muscidae) sebagai vektor mekanik infeksi jamur. Majalah Kesehatan Masyarakat Indonesia tahun XXV Nomor 8 September.

11. Hermawan, Benny. 1985. Beberapa faktor yang mempengaruhi masyarakat dalam pembuangan sampah di komplek Ditjen Bang. Desa Pasar Minggu Jakarta Selatan. APK-TS, Jakarta. 